Western University Scholarship@Western

Centre for the Study of International Economic

Centre for the Study of International Economic

Relations Working Papers

Relations

1987

\title{
Production, Trade and Migration with Differentiated, Skilled Workers
}

James R. Markusen

Follow this and additional works at: https://ir.lib.uwo.ca/economicscsier_wp

Part of the Economics Commons

Citation of this paper:

Markusen, James R.. "Production, Trade and Migration with Differentiated, Skilled Workers." Centre for the Study of International Economic Relations Working Papers, 8710C. London, ON: Department of Economics, University of Western Ontario (1987). 
ISSN $\quad 0228-4235$

ISBN 0-7714-0872-2

THE CENTRE FOR THE STUDY OF INTERNATIONAL ECONOMIC RELATIONS

WORKING PAPER N0. $8710 \mathrm{C}$

PRODUCTION, TRADE AND MIGRATION WITH

DIFFERENTIATED, SKILLED WORKERS

James R. Markusen

Department of Economics Library

JUL 91987

University of Western Ontario

This paper contains preliminary findings from research work still in progress and should not be quoted without prior approval of the author.

\section{DEPARTMENT OF ECONOMICS}

THE UNIVERSITY OF WESTERN ONTARIO

LONDON, ONTARIO

N6A 5 C2 


\title{
PRODUCTION, TRADE, AND MIGRATION WITH
}

DIFFERENTIATED, SKILLED WORKERS

\author{
James R. Markusen \\ Department of Economics \\ University of Western Ontario \\ London \\ Canada
}

\begin{abstract}
A model is developed in which the output of one traded sector (e.g., high tech) is produced using consultants who supply differentiated skilled services. An external economy is shown to exist which in turn implies (a) the sub-optimal supply of skilled specialists, (b) multiple equilibria, and (c) disadvantages for small and/or late developing economies. Although the results indicate a positive role for subsidies, the model emphasizes the need to subsidize the use, not training of skilled specialists. The latter policy subsidizes foreigners through emigration.
\end{abstract}

May, 1987

Funded under a Grant from

The Institute for Research on Public Policy

Department of Economics Library

JUL 91987

University of Western Ontario 


\begin{abstract}
"Canada has lost almost 18,000 scientists, engineers, and other professionals to the U.S. over the past five years while very few ever return" (Toronto Star, May 17, 1987, page F2)
\end{abstract}

\title{
1. Introduction
}

Recently, there has been a popular concern with a real or imagined nexus among such diverse factors as skilled workers, high tech, $R \& D$, and international trade policy. The notion seems to be that it is good for a country to specialize in high tech goods and services, and that appropriate government policies can engineer comparative advantage in this direction. Two of the more plausible reasons for believing that high tech is good are that (a) there are positive rents to be earned in these industries, and (b) high tech firms generate substantial externalities. The tools of comparative-advantage engineering could range from direct subsidies to firms to educational subsidies for engineers and scientists.

Many recent papers in international trade theory have focused on the existence of positive rents, and constructed models based on scale economies, product differentiation, and imperfect competition to analyze the possible benefits of an activist government industrial policy. Other papers have employed the concept of external economies of scale, beginning with Melvin (1969) and Herberg and Kemp (1969). However, the externalities are simply an ad hoc attempt to fit scale economies into a competitive general-equilibrium model and do not provide the micro-foundations needed to analyze industrial policy. The latter are provided by Ethier $(1979,1982)$ and Romer (1987).

The first purpose of this paper is to provide a model which attempts to capture certain features of industrial organization in high tech sectors and which lends support to the externality argument. The model is in the spirit of those of Ethier and Romer, except that the focus is on the individual 
rather than on the firm since migration is a primary issue here. The present paper is also primarily normative. The reasoning proceeds in four steps. Firms use the services of skilled specialists, such as engineering and management consultants, as inputs. These knowledge-based services are provided with a high fixed cost (in learning) and a low marginal cost (as in xeroxing blueprints for additional clients). (2) Increased specialization by consultants is productive, but is limited by the fixed costs of learning. Firms make decisions about hiring additional hours of existing consultants time, whereas the sector actually expands by increasing the division of labour; i.e., by adding new specialized consultants. (4) The implication of (2) and (3) is that, when firms expand, they confer a positive externality on other firms by helping to increase the division of labour and productive efficiency.

An external economy exists and the sector underproduces in competitive equilibrium. As has been pointed out before, such an externality may also imply the existence of multiple equilibria, and that a small and/or late developing economy is more likely to get stuck in a low-level equilibrium.

Based on these results, the second purpose of the paper is to analyze the role of public policy in encouraging the development of skilled specialists. A key point is that in the open economy, the externality lies in the underuse of specialists, not in their underproduction per se. An analysis is presented in which education or training subsidies to workers simply causes the additional specialists to emigrate, a welfare reducing policy for the home country and a welfare increasing policy for the foreign country. The appropriate policy subsidizes the use, not the education or training, of skilled specialists. 


\section{Skilled Workers and External Economies}

Good $\mathrm{Y}$ is produced with constant returns by a competitive industry, using labour and sector-specific capital. $\mathrm{X}$ is produced using skilled labour services $(S)$ and sector-specific capital $(K)$. Let $\tilde{S}$ denote a composite index of these services, and assume that the production function is Cobb-Douglas between $\mathrm{K}$ and $\tilde{\mathbf{s}}$.

$$
x=(\tilde{S})^{\alpha}(K)^{1-\alpha}
$$

$\tilde{\mathbf{S}}$ is in turn given by the C.E.S. production function

$$
\tilde{s}=\left[\sum_{i=1}^{n}\left(s_{i}\right)^{\beta}\right]^{1 / B} ; \quad 0<B \leq 1
$$

where $s_{i}$ are individual specialized services and $(0<B \leq 1)$ ensures that none is vital to produce $\tilde{\mathbf{S}}$ and, further, that additional specialized services can always be produced as conditions warrant ( $n$ is endogenous).

Each individual in the economy can supply $\ell=1$ units of labour to $Y$, or can supply $s=1$ units of a skilled service to $x$. The production set for an individual is shown in Figure 1 . If the individual chooses to supply only L, one unit can be supplied. If a skilled service is to be supplied, a learning cost of (1-f) is incurred, after which there are constant returns to time spent at either task. f gives the marginal cost of supplying an $S$ in terms of L given that $s=1$ is the maximum amount of a service that can be provided. In a "quasi-dynamic" interpretation, (1-f) is the proportion of the period that a specialist must spend learning, thus producing no output.

A single individual in autarky would likely divide his time between $\ell$ and $s$ so that both $X$ and $Y$ are positive. But as more individuals are added, each has less influence over marginal products (i.e., the marginal product 


\section{Figure 1}

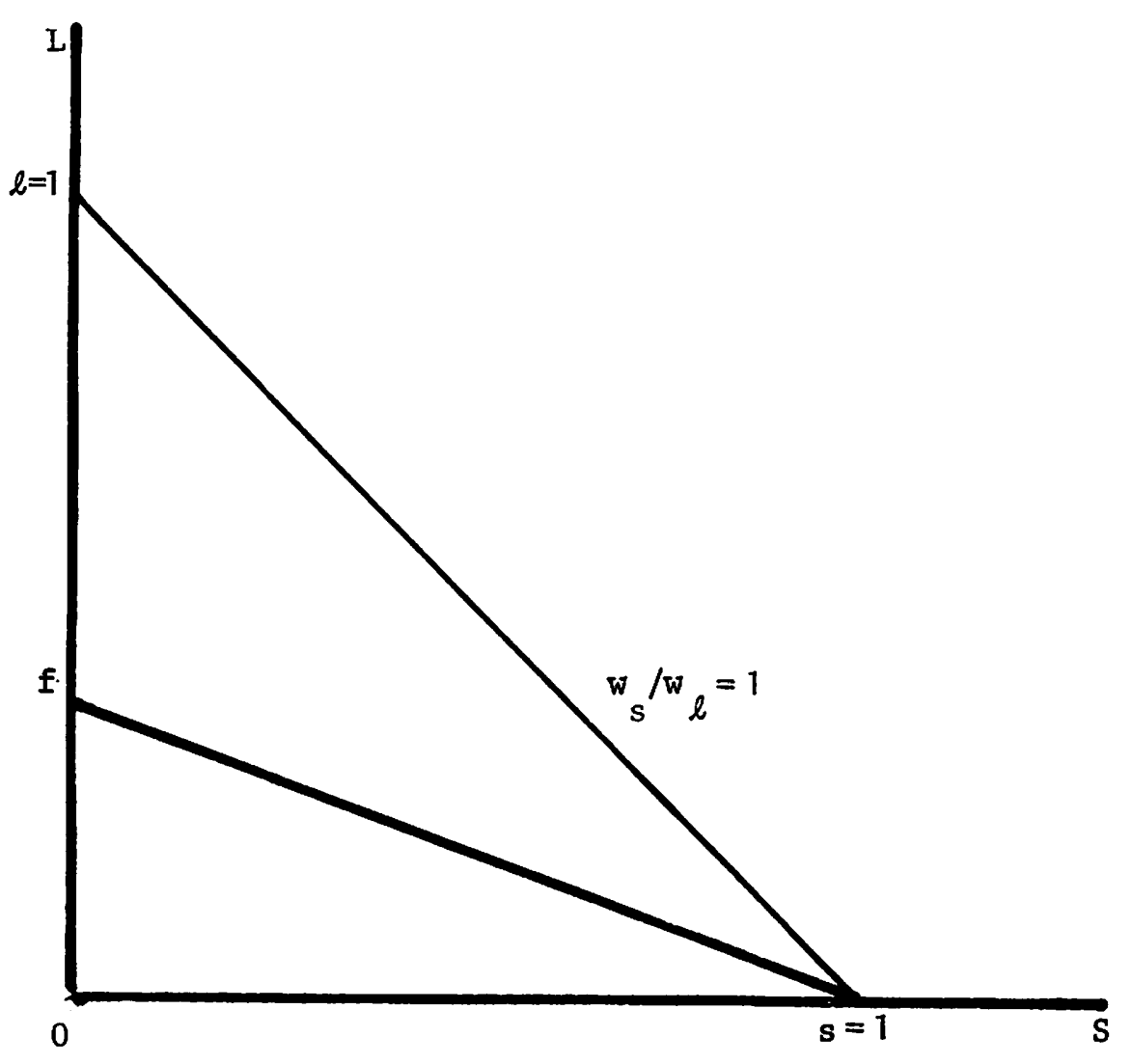

Figure 2

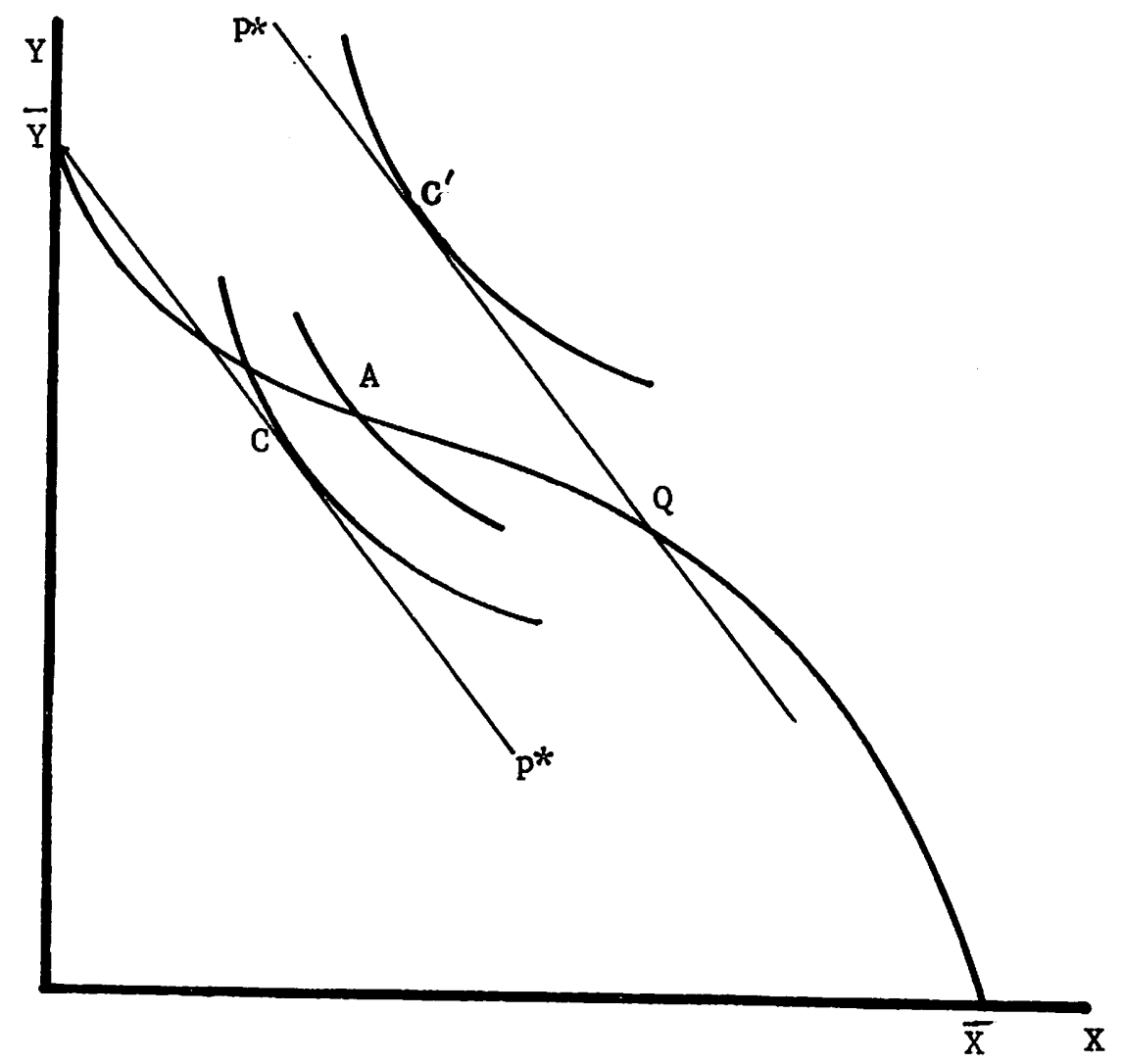


curves or factor demand curves faced by individuals become flatter) so individuals should specialize. We will assume for the remainder of the paper that there are a sufficient number of workers in the economy such that the non-convexity in the individual production sets shown in Figure 1 implies that each individual specializes.

An important implication of (2) is that any individual who chooses to supply a skilled service will do better by choosing a new service not currently provided. Thus any service which is provided will be provided in the quantity s. Equation (2) thus becomes

$$
\tilde{S}=\left[N(s)^{B}\right]^{1 / B}=N^{1 / B}(s)
$$

where $\mathrm{N}$ is the (endogenous) number of skilled services provided. N also gives the number of workers providing an $S$. Note that this formulation assumes that, although each individual supplier of $\mathbf{S}$ does have some market power, it does not pay the individual to reduce the length of his work at $s$ in order to raise the price of his $s$ (i.e., at $s=s$, marginal revenue exceeds the marginal opportunity cost of his time in performing $S$ instead of $L$ ). This will always be true provided that $(1-f)$ is sufficiently large or that $f$ is sufficiently small in Figure 1. Market equilibrium will leave each identical individual just indifferent to providing $L$ or an $S$, so that the relative wage $\left(w_{s} / w_{\ell}\right)$ must equal one as shown in Figure 1 . Of course, under the "quasi-dynamic" interpretation that (1-f) is the proportion of the period that a skilled worker spends learning, the skilled wage per unit of time worked is $w_{s} / f>w_{\ell}$.

Assume that the $X$ industry consists of a "large" number of identical firms. In order to focus on the issue of external economies of scale, we assume that firms have individually small demands for specialized services 
relative to $s$ (e.g., each firm requires each specialist for only a few hours per week/year). We further assume that each firm views the division of labour as exogenous but views the number of hours it uses each specialist as endogenous. Individual firms thus attempt to increase output by increasing $s_{i}$ in equations (1) and (2) above.

But anything that induces one firm to increase output induces all firms to do likewise. Since all specialists were initially fully employed and just earning their opportunity cost, this increased demand induces entry of new skilled specialists. Actual increases in industry output thus take the form of increases in $\mathrm{N}$ with the $s_{i}$ constant at $s_{i}=s=1$.

These assumptions have three important implications for market structure, industry supply, and general equilibrium. The first is that individual firms have or at least perceive themselves to have constant returns to scale technologies, while the industry production function has increasing returns to scale. A competitive equilibrium (equilibria) with external economies of scale can thus exist.

Increasing returns to the $X$ industry can be established by multiplying $K$ and $N$ in (3) by some scalar $\lambda$.

$$
\left(\lambda \mathrm{NS}^{\beta}\right)^{\alpha / \beta}(\lambda \mathrm{K})^{1-\alpha}=\lambda^{1+\alpha / \beta-\alpha}\left(\mathrm{NS}^{\beta}\right)^{\alpha / \beta}(\mathrm{K})^{1-\alpha}
$$

$X$ is then characterized by increasing returns since $1+\alpha / B-\alpha>1(1 / B>1)$. Firms, however, perceive themselves as expanding by increasing $K$ and $s_{i}$ holding $N$ constant. Constant returns to scale are demonstrated as follows.

$$
\left(\mathbb{N}(\lambda S)^{B}\right)^{\alpha / \beta}(\lambda K)^{1-\alpha}=\lambda^{(1+\alpha-\alpha)}\left(\operatorname{NS}^{B}\right)^{\alpha / \beta}(K)^{1-\alpha}
$$

which implies constant returns since $1+\alpha-\alpha=1$. The second implication of 
the technological and behavioral assumptions is that competitive equilibrium with $X>0$ will not be pareto optimal. We can show that price will always exceed the industry marginal cost of producing $x$ at a competitive equilibrium.

Let $\mathrm{MP}_{\ell \mathrm{x}}^{\star}$ denote the industry marginal product of labour in $\mathrm{X}$ and MP ${ }_{\ell X}$ denote the firm's marginal product of labour in $X$. Using (1), (2), and (3) above, these are given by:

$$
\begin{aligned}
& \operatorname{MP}_{\ell X}^{*} \equiv \frac{\partial X}{\partial N} \frac{1}{S_{i}}=(1 / B)(\tilde{S})^{\alpha / B-1}(S)^{B}(K)^{1-\alpha} \\
& \operatorname{MP}_{\ell X} \equiv \frac{\partial X}{\partial S_{i}} \frac{1}{N}=(1 / B)(\tilde{S})^{\alpha / B-1} B(S)^{B-1}(K)^{1-\alpha}
\end{aligned}
$$

Dividing (7) by (6), we have

$$
\operatorname{MP}_{\ell X} / \operatorname{MP}_{\ell X}^{*}=B / S=B<1 \text { at } s=1 \text {. }
$$

The private marginal product of labour in $X$ is less than the social marginal product of labour which is of course consistent with our earlier discussion of scale economies.

This result has a simple interpretation in a two-good general equilibrium formulation. Let $Y$ be a good produced with constant returns by a competitive industry. Suppose further that $Y$ uses labour and a sector specific factor capital, and that the economy's total labour and capital are in fixed supply. The production frontier of the economy can have all sorts of curious shapes as a consequence of scale economies in the $X$ industry (Herberg and Kemp (1969), Markusen and Melvin (1981, 1984)). If both industries have a constant elasticity of substitution between $L$ and $K$, for example, the production frontier must be as shown in Figure 2, convex to the origin near $X=0$ and concave near $X=\bar{X}$ with a single inflection point (Markusen (1987)). 
The distortion between the private and social marginal products of labour in $\mathrm{X}$ implies that a competitive equilibrium will not be characterized as a point of tangency between the price ratio $p\left(p=p_{x} / p_{y}\right)$ and the frontier $\bar{Y} \bar{X}$ in Figure 2. Since labour is the only factor of production used in $X$, the marginal cost of $X$ is simply $M_{X}=W_{\ell_{X}}$. Private marginal cost $\left(M C_{X}\right.$ ) and social marginal cost $\left(M C_{X}^{*}\right)$ are thus related by $M C_{X}(B)=M C_{x}^{*}$. Since private marginal cost is equal to price at a competitive equilibrium, we then have $\mathrm{PB}=M C_{\mathrm{X}}^{*}$ and $\mathrm{P}>\mathrm{MC}_{\mathrm{X}}^{*}$. A competitive equilibrium at price $p^{*}$ will be at a point like $Q$ in Figure 2 where $Q$ is on the frontier and where $p^{*} B=M R T=\left(M C_{x}^{*} / M C_{y}\right)$ along this locus.

A third implication of the model is that (a) there can exist multiple equilibria, (b) a "late entrant" is at a disadvantage in a trading equilibrium and (c) the smaller of two countries is at a disadvantage in a trading equilibrium. Consider a non-convex production frontier as shown in Figure 2. At price ratio $p^{*}$, two stable equilibria can exist as shown, with an unstable one in-between. One involves the country specializing in $Y$ and consuming at $C$ in Figure 2. The second involves production at $Q$ and consumption at $C^{\prime}$. The former is stable in that the price of $X$ is less than the marginal cost of producing $X$ in the neighborhood of $X=0$. The second is stable in that the marginal cost of producing $X$ is increasing along the concave segment of the production frontier. The welfare implications of being at the two equilibria are obviously very different.

Suppose now that we have two identical countries, each with the production frontiers $\overline{Y X}$ in Figure 2. In autarky, each country could be in equilibrium at point $A$. If $A$ is on the concave segment of the production frontier, it could also be a stable trading equilibrium in which each country 
did not in fact choose to trade. But suppose instead that one country did not have access to the technology to produce skilled workers for some reason in an initial trading situation. Then the situation shown in Figure 2 can be a trading equilibrium. The country without the $X(S)$ technology produces at $\bar{Y}$ and the other country produces at $Q$. Consumption and welfare levels are as shown.

Now suppose that the country specializing in $Y$ is given access to the $X$ technology. The equilibrium in Figure 2 just described continues to be a stable trading equilibrium. The price of $X$ is less than the marginal cost of producing $X$ in the neighborhood of $X=0$. The country that is the "late entrant" is stuck at the low-level equilibria while the "first entrant" enjoys a substantially higher welfare level even though both countries are now identical. The late entrant is indeed worse off than if it was now to erect a prohibitive tariff to trade.

Differences in country size raise a similar issue. Suppose that the large country has proportionally more of all factors (labour, $K_{x}$ and $k_{y}$ ) than the small country. Along any ray from the origin, the distorted production frontier of the large country is flatter than the production frontier of the small country. This is because at the common value of $\mathrm{Y} / \mathrm{X}$, the larger country produces an absolutely larger output of $\mathrm{X}$ and so enjoys a lower marginal cost of production due to the scale economies in $X$ (proved in Markusen and Melvin (1981)). In a free trade equilibrium, the small country must produce relatively more $Y$ and, if demand is identical and homothetic between countries, the smaller country will be the importer of $x$.

Two possible outcomes are shown in Figures 3 and 4 , where $\bar{Y}_{s} \bar{X}_{s}$ and $\bar{Y}_{\ell} \bar{X}_{\ell}$ 


\section{Figure 3}

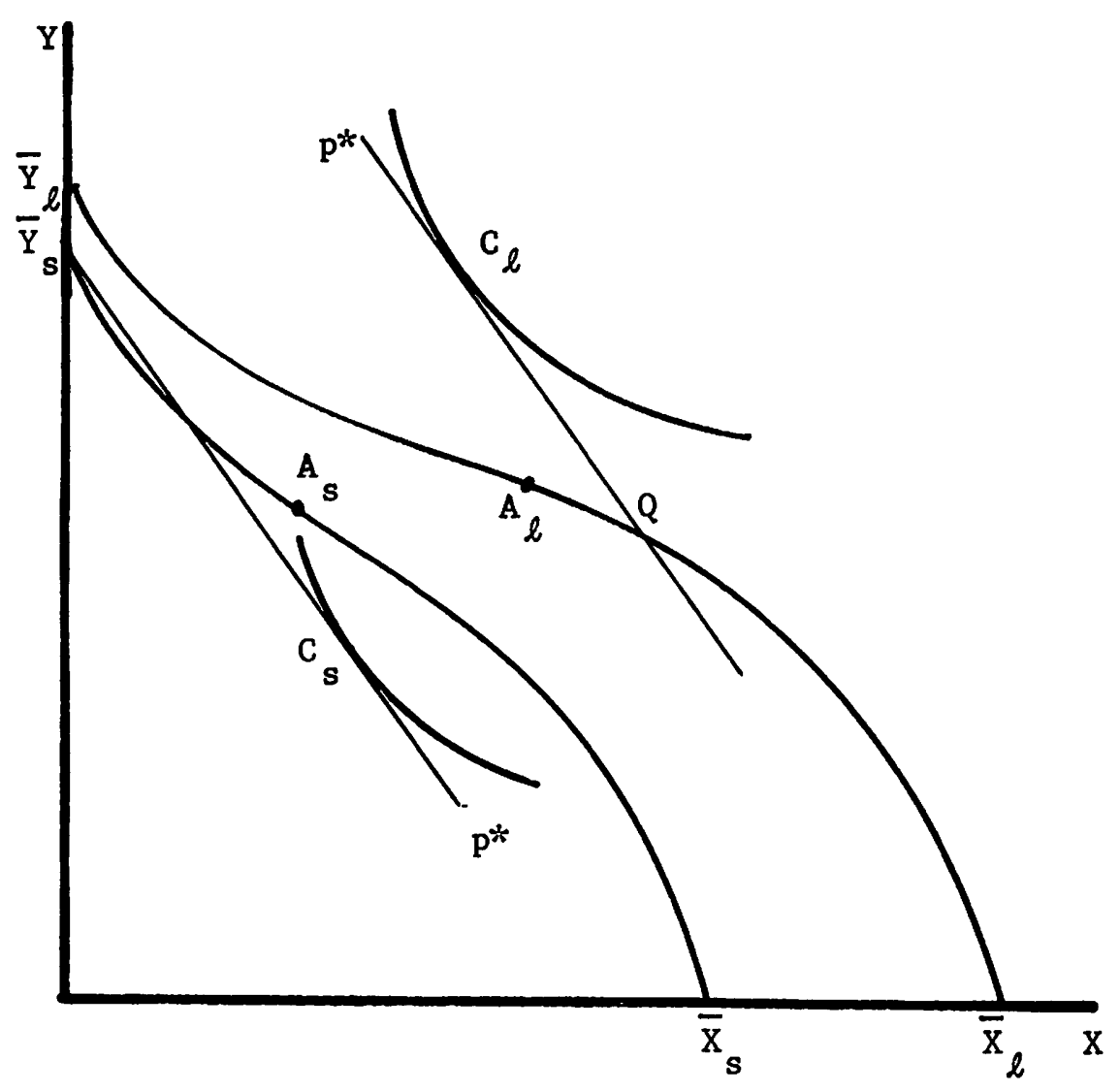

\section{Figure 4}

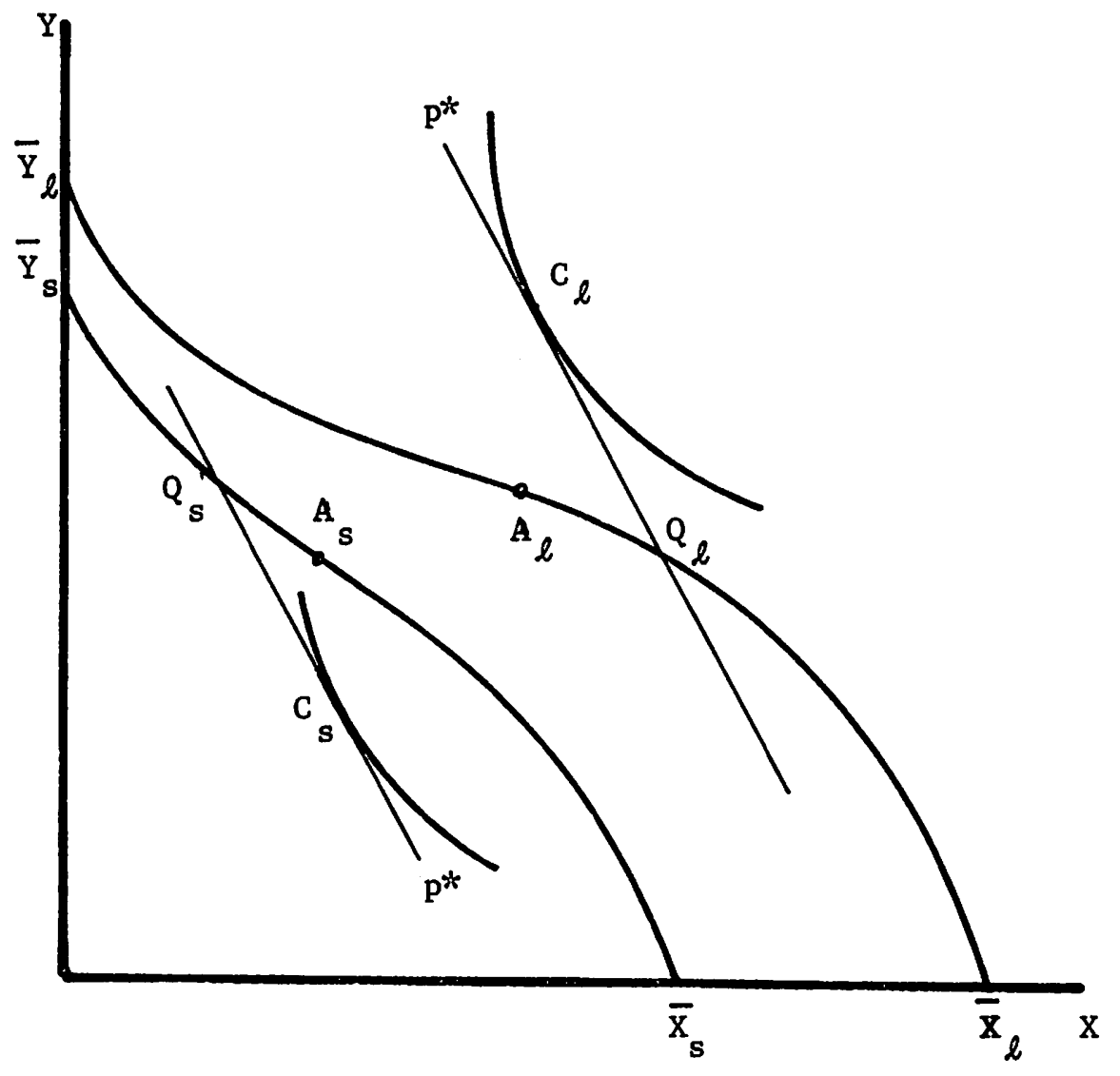


are the distorted production frontiers of the small and large countries respectively. Figure 3 shows the analog of Figure 2 where it is now the small country rather than the late entrant that is trapped at the low-level equilibrium specializing in $Y$. Figure 4 shows the case in which both countries are diversified. In each case, the production of $x$ in the small country must be less than at the autarky equilibrium $A^{s}$. When both countries are in autarky, the autarky price ratio $p$ must be greater in the small country than in the large country. This follows from the relationship between the slopes of their production frontiers as noted above plus the assumption of identical homothetic demand. The opening of trade must then drive down the output of $X$ in country $s$ and drive up the output in country $\ell$. Given the relationships between the autarky and trading equilibria shown in Figures 3 and 4 , it is clear that the large country will be better off with trade while the small country may or may not be better off relative to autarky. This result is demonstrated rigorously in Markusen and Melvin (1981, 1984), who show that an expansion in the output of the increasing returns sector is a sufficient condition for gains from trade. Contraction of output in the small country means that welfare may deteriorate relative to autarky. One policy which eliminates the small country late entrant problem is simply to allow the free migration of skilled labour. With commodity prices and the prices of skilled workers equalized by trade, the prices of unskilled workers and returns to sector-specific capital will also be equalized between countries having identical relative factor endowments. However, the distortion between price and marginal cost remains, and hence a role for further policy action exists. 
3. Human Gapital: Formation, Migration, and Policy

The purpose of this section is to consider explicitly policies that address the external economy problem outlined in the previous section. It is assumed that the economy allows free migration to counteract the "low-level equilibrium" problem as just outlined (note that this may not be in the other country's interest) and now considers action to address the price/cost distortion ( $P$ > MC).

As before, we have a two-good model in which good $Y$ is produced with constant returns by a competitive industry from unskilled labour and sector-specific capital. The production function for $\mathbf{Y}$ is

$$
Y=G\left(L_{y}, \bar{K}_{y}\right)
$$

$X$ will be produced with skilled labour and sector-specific capital $\overline{\mathbf{K}}_{\mathbf{X}}$. Individual workers in the $X$ sector can supply a unit of a differentiated skilled service $s=1$. Let $N$ equal the total number of skilled workers produced by the country, $\mathbb{N}_{e}$ the number of these that emigrate, and $\mathbb{N}_{i}$ the number of foreign skilled workers who immigrate. The domestic output of $\mathrm{X}$ is then

(10) $\quad X=\left(\mathbb{N}^{B}-\mathbb{N}_{e}^{B}+N_{i}^{B}\right)^{\alpha / B} \bar{K}_{x}^{-1-\alpha}$

$\mathrm{X}$ continues to be characterized by constant returns to the service levels and $K_{x}$ but increasing returns to the number of services and $K_{x}$. The total

labour supply constraint is given by $\bar{L}=L_{x}+L_{y}$.

Recall that the social and private marginal products of labour in $X$ are respectively

$$
\operatorname{MP}_{\ell X}=(\alpha / \beta)\left(N^{\beta}\right)^{\alpha / B-1} B \bar{K}^{-1-\alpha} \quad \operatorname{MP}_{\ell X}^{*}=(\alpha / B)\left(N^{\beta}\right)^{\alpha / B-1} \bar{K}^{-1-\alpha}
$$


The equation relating the two plus the competitive equilibrium condition are given as follows.

$$
\operatorname{MP}_{\ell X}=\operatorname{BMP}_{\ell x^{\prime}}^{*}, \quad \frac{w}{\mathbf{p}}=\operatorname{MP}_{\ell x}=\operatorname{BMP}_{\ell x}^{*}
$$

where $W$ is the wage rate in terms of $Y$. In the absence of taxes or subsidies, the wage rate $w$ must be equal to the price of a skilled worker, denoted $q$. Throughout this section, we will assume that both the commodity price ratio $p$ and the price of a skilled worker $q$ are fixed in the larger world market. This allows us to avoid terms-of-trade effects which are largely irrelevant for our purposes.

Differentiating the production functions for $Y$ and $X$, we have

$$
d Y=G^{\prime} d L_{y}=w d L_{y} \quad d X=\left(\operatorname{MP}_{\ell x}^{*}\right) d N-\left(\operatorname{MP}_{\ell x}^{*}\right) d N e+\left(\operatorname{MP}_{\ell x}^{*}\right) d N_{i}
$$

Multiplying the second equation by $p$ and noting that $\operatorname{pMP}_{\ell x}^{*}=w / B=q / B$ from (12), this equation can be written as

$$
\begin{aligned}
& p d X=(q / B) d N-(q / B) d N_{e}+(q / B) d N_{i} \text { or } \\
& p B d X=q d N-q d N e+q d N_{i}
\end{aligned}
$$

But $d \bar{L}=d L_{x}+d L_{y}=d N+d L_{y}=0$, thus $q d N=-q d L_{y}=-w d L_{y}=-d Y$.

(14) becomes

$$
p B d X=-d Y-q d N_{e}+q_{i} \quad \text { or } \quad d Y+p B d X+q d N=-q d N_{i}=0
$$

The welfare criterion is the per capita income of domestic citizens living in the country. It is however easier to work with their total income than per capita quantities. Let $C_{x}$ and $C_{y}$ denote the consumption of domestic citizens living in the country of goods $X$ and $Y$ respectively. That is, consumption of domestics who emigrate is not included nor is consumption 
of foreign skilled workers who immigrate. The domestic utility function is given by

$$
U=U\left(C_{y}, C_{x}\right)
$$

Differentiating and dividing by $u_{y}$, we have the change in welfare in terms of $\operatorname{good} Y(d W)$.

$$
d W=\frac{d U}{U_{y}}=d C_{y}+\frac{U_{x}}{U_{y}} d C_{x}=d C_{y}+p d C_{x}
$$

Balance of payments requires that the value of domestic production minus the payments to immigrant workers equal the value of domestic consumption as we have defined it.

$$
e_{y}+p^{*} e_{x}-q N_{i}=0 ; \quad e_{y}=Y-c_{y}, \quad e_{x}=X-c_{x}
$$

where $\mathrm{p}^{*}$ is the world price ratio. Differentiation of this balance-of-payments constraint gives us

$$
d e_{y}+p^{*} d e_{x}+e_{x} d p^{*}-q d N_{i}-N_{i} d q=0
$$

Assume as noted above that the world commodity price ratio is fixed as is the world price of a skilled worker $\left(d^{*}{ }^{*}=d q=0\right)$. Substituting (15) and (19) into (17) gives us

$$
\begin{aligned}
d W & =d Y-d e_{y}+p d X-p d e_{X} \\
& =-p B d X-q d N_{e}+q d N_{i}+p d X+\stackrel{*}{*} d e_{X}-q d N_{i}-p d e_{X}
\end{aligned}
$$

which simplifies to

$$
d W=p(1-B) d X+(q-q) d N_{i}-q d N_{e}+\left(p^{*}-p\right) d e_{x}
$$

The first term in (21) is the externality effect. With the private 
marginal cost of producing $X$ more than the true social marginal cost, increases in the output of $X$ improve welfare. The second term indicates that there is zero net gain from importing a foreign skilled worker (at constant $X$ ) since the wage paid is equal to the worker's productivity. The third term indicates the negative effect of emigration while the last term is a volume of trade effect if the domestic and foreign price ratios differ.

Now consider a production subsidy to $X$ of $r$ and/or a subsidy to the production of skilled workers of $v$. The price received by domestic $\mathrm{X}$ producers will be $p(1+r)$ while the price of a skilled worker will be related to the wage of an unskilled worker by $w(1-v)=q$. The second equation of (12) will then be replaced by

$$
\frac{w(1-v)}{p(1+r)}=\operatorname{BMP}_{1 X}^{*}
$$

Since the subsidy to the production of skilled workers is only paid to domestics educated at home, the new equivalent of (14) becomes

$$
\begin{aligned}
& \operatorname{pdX}=\frac{w(1-v)}{B(1+r)} d N-\frac{w(1-v)}{B(1+r)} d N_{e}+\frac{q}{B(1+r)} d N_{i} \\
& p B \frac{(1+r)}{(1-v)} d X=w d N-w d N_{e}+(q /(1-v)) d N_{i} \\
&=-d Y-w d N_{e}+(q /(1-v)) d N_{i}
\end{aligned}
$$

Making the same substitutions as in the above, the new version of (21) is

$$
d W=p\left(1-B \frac{(1+r)}{(1-v)}\right) d x+q\left(\frac{1}{1-v}-1\right) d N_{i}-w d N_{e}+\left(p^{*}-p\right) d e_{x}
$$

An optimal policy sets (24) equal to zero for all values of $d x, d N e$, $\mathrm{dN}_{i}$, and de ${ }_{x}$. First, there should be no import tariff or subsidy so that $p=p^{*}$. Second, the education subsidy $v$ should be set to zero. Third, the production subsidy should be set at $(1+r)=1 / B$ or $r=1 / B-1$. This 
leaves $d W=-w d W_{e}$. The production subsidy should pull domestics back to the economy $\left(d N_{e}<0\right)$ so this term contributes positively to welfare.

Alternatively, if we are only interested in the welfare of those citizens residing in the economy at the time the policy is imposed as we have assumed throughout this section, we simply ignore this term since it contributes only to GNP and not the per capita income of the orignal citizen-residents. Under this welfare criterion, the production subsidy is a full first-best optimum. The subsidy addresses the problem of the undersupply of skilled workers and is equivalent to subsidizing all skilled workers who work in the economy, rather than those who are educated in the economy.

Suppose instead that we subsidize the training of domestic citizens to become skilled workers. Competitive equilibrium in the $X$ industry requires that $q / p=M_{\ell x}$ or $q=\operatorname{pMP}_{\ell x}$ : the price of a skilled worker is equal to the value of his marginal product. With no taxes, tariffs, or subsidies on $X, p$ and $q$ are fixed by world prices. Thus the subsidy to domestic education must generate an adjustment process that leaves UP $_{\ell \times}$ unchanged. This in turn implies that the number of skilled workers in $X$ is unchanged (the sector-specific capital implies that the marginal product of labour is a function of the skilled labour input only). But if the domestic wage is unchanged, it is now profitable to become a skilled worker. Workers will leave $Y(d Y<0)$ until the wage is driven up to the point where $w(1-v)=q$. Combining $d L_{y}<0$ with $d N-d N e+d N_{i}=0$ implies that $d N_{e}>0$ and/or $\mathrm{dN}_{i}<0$. Subsidizing the education of domestic skilled workers leaves the output of the $X$ sector unchanged and merely causes some of the skilled workers to leave, whether they be domestics emigrating or some of resident foreigners returning home. 
With $\mathrm{dX}=0$ and no tariff $\left(p^{*}-p=0\right)$, the welfare expression in (24) becomes

$$
\begin{aligned}
d w & =q\left(\frac{1}{1-v}-1\right) d N_{i}-w d N_{e} \\
& =q\left(\frac{1}{1-v}-1\right) d N_{i}-q\left(\frac{1}{1-v}\right) d N_{e}<0
\end{aligned}
$$

The sign of (25) follows from the fact that we have just established that $\mathrm{dN}_{i}<0$ and/or $\mathrm{dN}_{\mathrm{e}}>0$. If the subsidy to the creation of domestic skilled workers causes foreign skilled workers to leave, the economy loses the difference between the value of produced by a foreign worker $q /(1-v)$ and the wage paid to the foreign worker $q$. If domestic workers leave, the loss to the economy is $q /(1-v)$ for each emigrating worker. This loss is greater than the income received by that worker, which is $q$.

The results of this and the previous sections can now be summarized as follows. The external economies model based on the creation of human capital and skilled workers suggests a role for public policy in encouraging via direct or indirect subsidies the output of the relevant sectors. But in the open economy, there is a great deal of difference between subsidizing the use of these skilled services and subsidizing the creation of them. While the former policy is welfare improving, the latter policy only subsidizes foreigners in the model via a "brain drain" type of phenomenon. Subsidizing the education of Canadian scientists, engineers, and doctors may constitute a transfer to the United States. Note finally from (24) that the production subsidy continues to be optimal if Canadians cannot enter the U.S. but skilled Americans can enter Canada. The term wdN $e$ is now zero and $[v=0, r=(1 / B-1)]$ continues to be the optimal policy. 


\section{Summary and Policy Implications}

The purpose of this paper was to consider certain factors relating to skilled workers and human capital that may characterize high-tech sectors of the economy. The idea was to evaluate the notion that such sectors generate externalities and thus deserve support from public policy. A model was developed in which firms in one sector use the services of specialized consultants, the latter providing their services to more than one firm. An external economy was shown to exist in that, when one firm expands, it confers positive externalities on other firms by helping to increase the division of labour.

The implication of the external economy/specialized consultant model is that the sector as a whole underproduces in a competitive equilibrium. Combining this with the possible existence of multiple equilibria implies that the a country can get "stuck" at a low-level equilibrium in which welfare is significantly less than at alternative equilibria. Two considerations, which are particularly relevant to Canada in its trading relationship with the U.S., were shown to increase the probability of getting stuck at a low-level equilibrium: first, if the country is smaller than its trading partner and second, if the country is a late entrant in developing the technology or factors necessary to produce the skilled workers necessary to support the external economies sector.

It was noted that allowing free migration of skilled workers of fered a solution to the small economy/late entrant problem. Free migration plus free trade in goods leads to factor-price equalization in the model. Per capita incomes are equalized for countries with the same relative factor endowments and production occurs on the efficient world production frontier. However, 
the distortion between price and marginal cost remains, so real income is not maximized simply by a free trade/migration policy (the most efficient point on the world product possibilities frontier is not chosen in competitive equilibrium).

The model thus implies a role for the government to support the development of the external economies sector. The policy section of the paper, however, emphasized that the means chosen to support the sector are critical for the success of the policy. Two options were considered. First, a subsidy to the output of the sector was considered. Second, a subsidy to the education of the skilled workers was examined. In a closed economy the two would be roughly the same except that the latter could induce an inefficient substitution between skilled and unskilled workers (this did not occur in our model since skilled workers were assumed to be the only variable input). But in the open economy, the two policies are very different. The production subsidy was shown to be a first best option. The education subsidy was, on the other hand, shown to be welfare worsening. The increased numbers of educated workers drove down the return to skilled labour and hence equilibrium was restored by emigration of some of those workers, or by the repatriation of foreign skilled workers. The education subsidy in the model subsidizes the foreign country. 
REFERENCES

Ethier, Wilfred (1979), "Internationally Decreasing Cost and World Trade," Journal of International Economics 9, 1-24.

Ethier, Wilfred (1982), "National and International Returns to Scale in the Hodern Theory of International Trade," American Economic Review 72 , 389-405.

Herberg, H. and M.C. Kemp (1969), "Some Implications of Variable Returns to Scale," Canadian Journal of Economics II, 403-415.

Kemp, M.C., and H. Herberg (1971), "Factor Market Distortions, the Shape of the Locus of Competitive Outputs, and the Relation between Product Prices and Equilibrium Outputs," in Trade, Balance of Payments and Growth, edited by J.N. Bhagwati et al. (Amsterdam: North-Holland). Markusen, James R. (1987), "Trade in Producer Services and in Other Specialized Intermediate Inputs", University of Westen Ontario working paper.

Markusen, J.R. and J.R. Melvin (1981), "Trade, Factor Prices, and the Gains from Trade with Increasing Returns to Scale," Canadian Journal of Economics XIV, 450-469.

Markusen, James R. and James R. Melvin (1984), "The Gains from Trade Theorem with Increasing Returns to Scale", in Henryk Kierzkowski (editor), Monopolistic Competition in International Trade (Cambridge: Cambridge University Press).

Melvin, J.R. (1969), "Increasing Returns to Scale as a Determinant of Trade," Canadian Journal of Economics II, 389-402.

Romer, Paul M. (1987), "Growth Based on Increasing Returns Due to Specialization," American Economic Review 77, 56-62. 
8501C Greenwood, Jeremy and Kent P. Kimbrough. FOREIGN EXCHANGE CONTROLS IN A BLACK MARKET ECONOMY.

8502C Horstmann, Ignatius and James R. Markusen. UP YOUR AVERAGE COST CURVE: INEEFICIENT ENTRY AND THE NEN PROTECTIONISM.

8503C Gregory, Allan W. TESTING INTEREST RATE PARITY AND RATIONAL EXPECTATIONS FOR CANADA AND THE UNITED STATES.

$8504 \mathrm{C}$ Kuhn, Peter and Ian Hooton. INTERNATIONAL FACTOR MOVEMENTS IN THE PRESENCE OF A FIXED FACTOR.

8505C Wong, Kar-yiu. GAINS FROM GOODS TRADE AND FACTOR MOBILITY.

8506C Heller, Paul and Makoto Yano. FUTURES MARKETS, REAL INCOME, AND SPOT PRICE VARIABחITY: A GENERAL EỌUIIIBRIUM APPROACH.

8507C D lewert, W.E. THE EFFECTS OP AN INNOVATION: A TRADE THEORY APPROACH.

8508C Ethier, WHIfred J. POREIGN DIRECT INVESTMENT AND THE MULTINATIONAL FIRM.

8509C Dinopoulos, E11as. INSIDE THE BLACX BOX: (IN)TANGIBLE ASSETS, INTRA-INDUSTRY INVESTMENT AND TRADE.

8510C Jones, R1chard, John Whalley, and Randall Higle. REGIONAL IMPACTS OF TARIFFS IN CANADA: PRELIMINARY RESULTS FROM A SMALL DIMENSIONAL NUMERICAL GĖNERAL EOUUIL IBRIUM MODEL.

8511C Whalley, John. IIDDEN CHALLENGES IN RECENT APPLIED GENERAL EQUIL IBRIUM EXERCISES.

3512C Smith, Bruce. SOME COLONIAL EVIDENCE ON THO THEORIES OF MONEY: MARYLAND AND THE CAROLINAS.

9513C Grossman, S.J., A. Melino, and R.J. Sh1ller. ESTIMATING THE CONTINUOUS TIME CONSUMPTION BASED ASSET PRICING MODEL.

8514C Romer, Paul R. TAX EFFECTS AND TRANSACTION COSTS FOR SHORT TERM MARKET DISCOUNT BONDS.

8515C MCCallum, Bennett T. ON CONSEỌUENCES AND CRITJCISMS OF MONETARY TARGETING.

8516C Dinopoulos, Ellas and Ian Wooton. A NORTH-SOUTH MODEL OF INTERNATIONAL JUSTICE.

8517C Huffman, Gregory W. A DYNAMIC EQUILIBRIUM MODEL OF ASSET PRICES AND TRANSACTION VOLUME.

8518C Huffman, Gregory W. AN ALTERNATIVE VIEW OF OPTIMAL SEIGNIORAGE. 8519C Huffman, Gregory W. ASSET PRICING WITH HETERGENEOUS ASSETS. 
8520C Hercowitz, Zv1. THE REAL INTEREST RATE AND AGGREGATE SUPPLY.

8521C Davies, James and Michael Hoy. COMPARING INCOME DISTRIBUTIONS UNDER AVERSION TO DOWNSIDE INEQUAIITY.

8522C Nguyen, Trien $T$. and John Whalley. COEXISTENCE OF EQUIIIBRIA ON BLACK AND WHITE MARKETS.

8523C Clarete, Ramon and John Whalley. INTERACTIONS BETWEEN TRADE POLICIES AND DOMESTIC DISTORTIONS: THE PHILIPPINE CASE.

8524C Hamilton, Bob, Shar1f Mohammad, and John Whalley. APPLIED GENERAL EQUILIBRIUM ANALYSIS AND PERSPECTIVES ON GROWTH PERFORMANCE.

8525C Huffman, Gregory W. THE LAGGED EFFECTS OF POLICY ON THE PRICE LEVEL.

8526C Laidler, David. FISCAL DEFICITS AND INTERNATIONAL MONETARY
INSTITUTIONS.

8527C Goodfriend, Marvin. MONETARY MYSTIQUE: SECRECY AND CENTRAL
BANKING.

8528C Nguyen, Trien $T$. and. John Whalley. GENERAL EQUILIBRIUN ANALYSIS OF PRICE CONTROLS A TWO-SECTOR COMPUTATIONAL APPROACH.

8529C Heckman, James J. and $V$. Joseph Hotz. AN INVESTIGATION OF THE LABOR MARKET EARNINGS OF PANAMANIAN MALES: EVALUATING SOURCES OF INEQUALITY.

8530C Greenwood, Jeremy and Gregory W. Huffman. A DYNAMIC EQUIIIBRIUM MODEL OF INFLATION AND UNEMPLOYMENT.

8531C Freeman, Scott. INSIDE MONEY, MONETARY CONTRACTIONS, AND WELFARE. 8532C Paderanga, Cayetano Jr. and Ian Wooton. A POSITIVE VIEW OF
INFANT INDUSTRIES.

8533C St-H1laire, France and John Whalley. A MICROCONSISTENT DATA SET FOR CANADA FOR USE IN REGIONAI GENERAL EQUILIBRIUM POLICY ANALYSIS.

8534C Whalley, John. OPERATIONALIZING WALRAS: EXPERIENCE WITH RECENT APPLIED GENERAL EQUILIBRIUM TAX MODELS.

8535C Melvin, James R. THE GENERAL NON-EQUIVALENCE OF TARIFFS AND IMPORT QUOTAS. 
8601C Greenwood, Jeremy and R. Preston MCAfee. EXIERNALITIES AND ASYMETRIC INFORMATION.

8602C Dinopoulos, Elias and Mordecha1 E. Kreln1n. IMPORT OQUOTAS AND VERS: A COMPARATIVE ANALYSIS IN A THREE-COUNTRY FRAMEWORK.

8603C Clarete, Ramon and John Whalley. COMPARING THE MARGINAL WELFARE COSTS OF COMMODITY AND TRADE TAXES.

8604C Wigle, Randy. CANADIAN TRADE LIBERALIZATION: SCALE ECONOMES IN A GLOBAL CONTEXT.

8605C Parkin, Michael. DOMESTIC MONETARY INSTITUTIONS AND FISCAL DEFICITS.

8606C Dinopoulos, Ellas and Ian Wooton. INTERNATIONAL TRADE AND THE ACQUISITION OF SKILLS.

8607C Kawasaki, Selichi and John McMillan. THE DESIGN OF CONTRACTS: EVIDENCE FROM JAPANESE SUBCONTRACTING.

8608C Williamson, Stephen D. LIQUIDITY, BANKING, AND BANK FAILURES.

8609C Grossman, Gene M. and Carl Shapiro. COUNTERFEIT-PRODUCT TRADE.

8610C Deardorff, Alan V. WHY DO GOVERNMENTS PREFER NONTARIFF BARRIERS?

8611C Horstmann, Ignatius and James R. Markusen. LICENSING VERSUS DIRECT INVESTMENT: A MODEL OF INTERNALIZATION BY THE MUTINATIONAL ENTERPRISE.

8612C Thursby, Jerry G. and Marie C. Thursby. BIIATERAL TRADE FLOWS, THE LINDER HYPOTHESIS, AND EXCHANGE RISK.

8613C Clarete, Ramon and John Whalley. EQUIIIBRIUM IN THE PRESENCE OF FOREIGN EXCHANGE PREMIA.

8614C Wooton, Ian. TOWARDS A COMMON MARKET: FACTOR MOBILITY IN A CUSTOMS UNION.

8615C St-H1laire, France and John Whalley. SOME ESTIMATES OF TRADE FLOWS IN BANKING SERVICES.

8616C Evenson, Robert E. and Cayetano Paderanga Jr. RURAL LABOUR MARKETS, TRANSACTION COST AND PERTIIITY.

8617C Fried, Joel and Peter Howitt. FISCAL DEFICITS, INTERNATIONAL TRADE AND WELFARE.

8618C Trela, Irene, John Whalley, and Randy Wigle. INTERNATIONAL TRADE. IN AGRICULTURE: DOMESTIC POLICIES, TRADE CONFLICTS, AND NEGOTIATING OPTIONS. 
8619C Markusen, James R. and Anthony J. Venables. TRADE POLICY WITH INCREASING RETURNS AND IMPERFECT COMPETITION: CONTRADICTORY RESULTS FROM COMPETING ASSUMPTIONS.

8620C Hunter, Linda and James R. Markusen. PER-CAPITA INCOME AS A DETERMINANT OF TRADE.

8621C Jones, Rich and John Whalley. A CANADIAN REGIONAL GENERAL EQUILIBRIUM MODEL AND SOME APPLICATIONS.

8622C Freeman, Scott, and Gregory W. Huffman. INSIDE MONEY, OUTPUT, AND CAUSALITY.

8623C Hamilton, Colleen, and John Whalley. DEALING WITH THE NORTH: DEVELOPING COUNTRIES AND GLOBAL TRADE NEGOTIATIONS.

8624C Williamson, Stephen D. LAISSEZ FAIRE BANKING AND CIRCULATING MEDIA OF EXCHANGE.

8625C Whalley, John. WHAT HAVE WE LEARNED FROM GENERAL EQUILIBRIUM TAX POLICY MODELS?

8626C Bhatia, Kul B. SHORT RUN AND LONG RUN IN THE THEORY OF TAX INCIDENCE.

8627C Jones, Rich, and John Whalley. REGIONAL EFFECTS OF TAXES IN CANADA: AN APPLIED GENERAL EQUILIBRIUM APPROACH.

8628C Nguyen, Trien T., and John Whalley. GENERAL EQUILIBRIUM WORLD TRADE UNDER BILATERAL OQUOTAS.

8629C Clarete, Ramon L., and James A. Roumasset. THE RELATIVE WELFARE COST OF INDUSTRIAL AND AGRICULTURAL PROTECTION POLICIES USING PHILIPPINE DATA. 
8701C McMillan, John, John Whalley, and Zhu Li Jing. INCENTIVE EFFECTS OF PRICE RISES AND PAYMENT-SYSTEM CHANGES ON CHINESE AGRICULTURAL PRODUCTIVITY GROWTH.

8702C Wooton, Ian. CAPITAL, SKILLS, AND INTERNATIONAL TRADE.

8703C Ryan, Cillian. TRADE IN THE PRESENCE OF ENDOGENOUS INTERMEDIATION IN AN ASYMMETRIC WORLD.

8704C Kennan, John and Raymond Riezman. OPTIMAL TARIFF EQQUILIBRIA WITH CUSTOMS UNIONS.

8705C Feenstra, Robert C., and Tracy R. Lewis. NEGOTIATED TRADE RESTRICTIONS WITH PRIVATE POLITICAL PRESSURE.

8706C Brecher, Richard A. POLICY-INDUCED INFLOWS OF FOREIGN CAPITAL IN THE PRESENCE OF RIGID-WAGE UNEMPLOYMENT.

8707C Harrison, Glenn W., Richard Jones, Larry J. Kimbell, and Randall Wigle. HOW ROBUST IS APPLIED GENERAL EQUILIBRIUM ANALYSIS?

8708C Jones, Rich and John Whalley. REGIONAL BALANCE SHEETS OF GAINS AND LOSSES FROM NATIONAL POLICIES.

8709C Markusen, James R. TRADE IN PRODUCER SERVICES AND IN OTHER SPECIALIZED INTERMEDIATE INPUTS.

8710C Markusen, James R. PRODUCTION, TRADE, AND MIGRATION HITH DIFFERENTIATED, SKILLED WORKERS.

8711C Markusen, James R. INTRA-FIRM SERVICE TRADE BY THE MULTINATIONAL ENTERPRISE. 